\title{
Analysis of Petroleum System for Exploration and Risk Reduction in Abu Madi/Elqar'a Gas Field, Nile Delta, Egypt
}

\author{
Said Keshta, ${ }^{1}$ Farouk J. Metwalli, ${ }^{2}$ and H. S. Al Arabi ${ }^{3}$ \\ ${ }^{1}$ Geology Department, Faculty of Education, Suez Canal University, Arish, Egypt \\ ${ }^{2}$ Geology Department, Faculty of Science, Helwan University, Cairo, Egypt \\ ${ }^{3}$ Geology Department, Faculty of Science, Suez Canal University, Ismailia, Egypt
}

Correspondence should be addressed to Said Keshta, said974@yahoo.com

Received 15 February 2012; Revised 21 May 2012; Accepted 22 May 2012

Academic Editor: Jean-Pierre Burg

Copyright (C) 2012 Said Keshta et al. This is an open access article distributed under the Creative Commons Attribution License, which permits unrestricted use, distribution, and reproduction in any medium, provided the original work is properly cited.

\begin{abstract}
Abu Madi/El Qar'a is a giant field located in the north eastern part of Nile Delta and is an important hydrocarbon province in Egypt, but the origin of hydrocarbons and their migration are not fully understood. In this paper, organic matter content, type, and maturity of source rocks have been evaluated and integrated with the results of basin modeling to improve our understanding of burial history and timing of hydrocarbon generation. Modeling of the empirical data of source rock suggests that the Abu Madi formation entered the oil in the middle to upper Miocene, while the Sidi Salem formation entered the oil window in the lower Miocene. Charge risks increase in the deeper basin megasequences in which migration hydrocarbons must traverse the basin updip. The migration pathways were principally lateral ramps and faults which enabled migration into the shallower middle to upper Miocene reservoirs. Basin modeling that incorporated an analysis of the petroleum system in the Abu Madi/El Qar'a field can help guide the next exploration phase, while oil exploration is now focused along post-late Miocene migration paths. These results suggest that deeper sections may have reservoirs charged with significant unrealized gas potential.
\end{abstract}

\section{Introduction}

The Nile Delta basin contains a thick sequence of potential hydrocarbon source rocks that generate essentially gas and condensate.

The Nile Delta is generally known as a natural gas-prone (essentially methane/gas condensate) region with production from Miocene and Pliocene fields. However, temperature and pressure data from these fields suggest that the Nile Delta basin should be oil rather than gas prone [1].

The purpose of this paper is to evaluate potential source rocks in north eastern part of Nile Delta from available geochemical data from two wells. An additional objective is to study the regional petroleum systems by using numerical models which provide information about burial and temperature history, maturation of source rocks and timing of expulsion of hydrocarbons. Maturity information was used for calibration of numerical models.
Sharaf [2] showed from organic geochemical and petrographic analyses that the kerogen in the early Pliocene mudstones of the Kafr El-Sheikh formation and the Tortonian Wakar formation in the NE of the Nile Delta has poor capability to generate gas and minor oil. These formations are immature in all of the wells he studied. However, the early Miocene Qantara and the Middle Miocene Sidi Salem formations have a poor potential to generate gas and minor oil in the southern part of the area, further north Sharaf [2]. They have improved capability to generate oil and minor gas. These formations are immature in the southern parts of the area but are within the oil zone in the northern part [2].

In general, the kerogen in the Pliocene and MiddleLate Miocene samples from the NE Nile Delta is mainly of Continental origin. Terrestrial woody and herbaceous fragments [2] are the main components with a minor content of amorphous organic matter (AOM) and marine phytoplankton. In the Early Miocene and Oligocene samples 


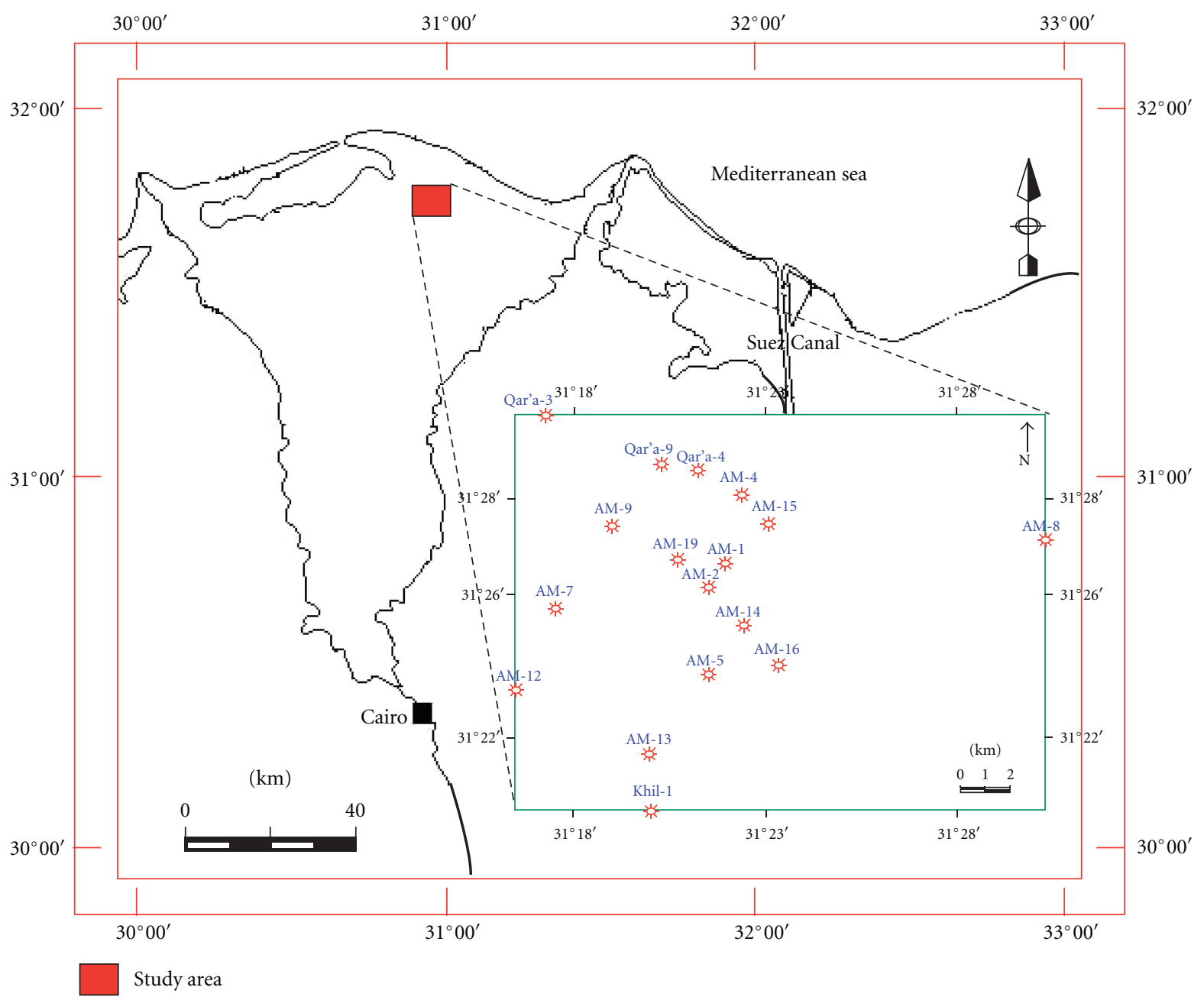

Figure 1: Location map of the study area.

from above $3500 \mathrm{~m}$, the kerogen is mainly of Terrestrial origin. Below this depth, the kerogen quality improves with increasing depth (the content of AOM increases to $75 \%$ and the Terrestrial fragments decrease to $20 \%$ ). The Eocene to late Cretaceous samples are characterized by moderate to high AOM and marine phytoplankton contents typical of kerogen with a good to fair petroleum generation potential. In the early-middle Cretaceous and late Jurassic samples, the kerogen is an amorphous-woody-algal assemblage accompanied by significant proportion of inertinitic debris [2].

\section{The Area of Study}

The area of study covers the onshore concession within Nile Delta. It lies between latitudes $31^{\circ} 20^{\prime}$ and $31^{\circ} 35^{\prime} \mathrm{N}$ and longitudes $31^{\circ} 15^{\prime}$ and $31^{\circ} 30^{\prime} \mathrm{E}$ (Figure 1). A total of 30 wells were drilled, of which 21 are in Abu Madi lease and 9 wells are in the El Qar'a lease. Twenty-four wells gave positive results and six wells were plugged and abandoned as dry holes, (five wells in Abu Madi lease and one well in El Qar'a lease (Figure 1). As a matter of fact, Abu Madi field is the first commercial discovery in the Nile Delta, where the IEOC achieved the first gas discovery from the early pliocene Abu Madi formation in the northeastern part of the onshore Delta by drilling the Abu madi-1 well, encounteringtwo pay zones with more than $50 \mathrm{~m}$ thick gas and condensate bearing sands in Abu Madi formation [4]. The field was put on production in 1975 and was producing 355 MMSCF per day in 1995 [4].

\section{Geological Setting}

The sedimentary section in the Nile Delta area with gas potential seems to be limited to the Neogene formations trapped against listric faults or draped over tilted fault blocks. However pre-Miocene formations of the base of this Neogene sequence may also be considered as future exploration plays. Mesozoic reservoirs are present at greater depth and have been only penetrated by a few wells which are mostly located in the south delta block.

The sedimentary rocks penetrated in Abu Madi/El Qar'a field consist of thick clastics representing Miocene-Holocene time interval. These rocks were described by El Heiny and Enani [3], Figure 2, Alfy et al. [5], and Sarhan and Hemdan [6]. 
FIgURE 2: Generalized lithostratigraphic column of Abu Madi gas field modified after [3].

TABLE 1: Summary of pyrolysis data of Abu Madi-9 well.

\begin{tabular}{lcccccccccc}
\hline Depth (M) & TOC & $S 1$ & $S 2$ & $S 3$ & $T_{\max }$ & HI & OI & $S 2 / S 3$ & $\% R_{o}$ & TTI \\
\hline 3067 & 0.68 & 0.15 & 0.51 & 0.85 & 427 & 75 & 125 & 0.6 & 0.6 & 9 \\
3154 & 1.21 & 0.17 & 2.74 & 1.1 & 429 & 226 & 91 & 2.49 & 0.62 & 12 \\
3184 & 1.12 & 0.14 & 2.1 & 0.95 & 429 & 187 & 85 & 2.21 & 0.6 & 9 \\
3224 & 1.37 & 0.1 & 1.06 & 1.01 & 431 & 77 & 74 & 1.05 & 0.5 & 3 \\
3256 & 1.54 & 0.05 & 1.1 & 1.06 & 434 & 72 & 69 & 1.04 & 0.7 & 20 \\
3310 & 1.85 & 0.1 & 1.74 & 0.7 & 434 & 94 & 38 & 2.49 & 1.1 & 98 \\
3344 & 0.81 & 0.09 & 0.71 & 0.25 & 436 & 87 & 31 & 2.84 & 1.3 \\
3358 & 0.58 & 0.13 & 0.63 & 0.24 & 437 & 108 & 42 & 2.63 & 0.9 & 48 \\
3390 & 0.51 & 0.25 & 0.25 & 0.17 & 439 & 49 & 34 & 1.47 & 1.35 & 179 \\
\hline
\end{tabular}

The studied section involves lithostratigraphic units ranging in age from Miocene to Holocene. The studied section is differentiated into the rock units: Qantara, Sidi Salem, Qawasim, and Abu Madi formations of the Miocene age; Kafr El Sheikh and El Wastani formations of the Pliocene age; Mit Ghamer formation of late Pliocene-Pleistocene age and the Bilqas formation of recent age. All these Formations consist essentially of clastic sediments (shale, sand, and silt).

\section{Materials and Methods}

One directional modeling of burial history and thermal maturity was preformed on five wells using basin mod Platter 
TABLE 2: Summary of pyrolysis data of Abu Madi-11 well.

\begin{tabular}{lcccccccccc}
\hline Depth $(\mathrm{M})$ & TOC & $S 1$ & $S 2$ & $S 3$ & $T_{\max }$ & HI & OI & $S 2 / S 3$ & $\% R_{o}$ & TTI \\
\hline 3108 & 1.5 & 0.07 & 1.38 & 1.95 & 429 & 89 & 125 & 0.71 & 0.49 & 0.8 \\
3186 & 1.26 & 0.1 & 1.27 & 1.41 & 430 & 101 & 112 & 0.9 & 0.55 & 7 \\
3210 & 1.65 & 0.06 & 1.42 & 1.7 & 431 & 86 & 103 & 0.84 & 0.71 & 21 \\
3231 & 1.57 & 0.09 & 1.54 & 1.56 & 432 & 98 & 99 & 0.99 & 0.67 & 18 \\
3250 & 1.62 & 0.11 & 1.41 & 1.07 & 432 & 87 & 66 & 1.32 & 0.88 & 44 \\
3293 & 1.27 & 0.2 & 1.42 & 1.04 & 436 & 112 & 82 & 1.37 & 0.7 \\
3318 & 0.82 & 0.05 & 0.75 & 0.77 & 435 & 91 & 94 & 0.97 & 0.68 \\
3400 & 1.66 & 0.08 & 1.61 & 0.86 & 435 & 97 & 52 & 1.87 & 1.1 \\
3425 & 2.03 & 0.1 & 0.91 & 1.02 & 436 & 45 & 50 & 0.89 & 1.15 & 112 \\
3460 & 1.74 & 0.14 & 1.53 & 0.84 & 436 & 88 & 48 & 1.82 & 1.3 & 165 \\
\hline
\end{tabular}

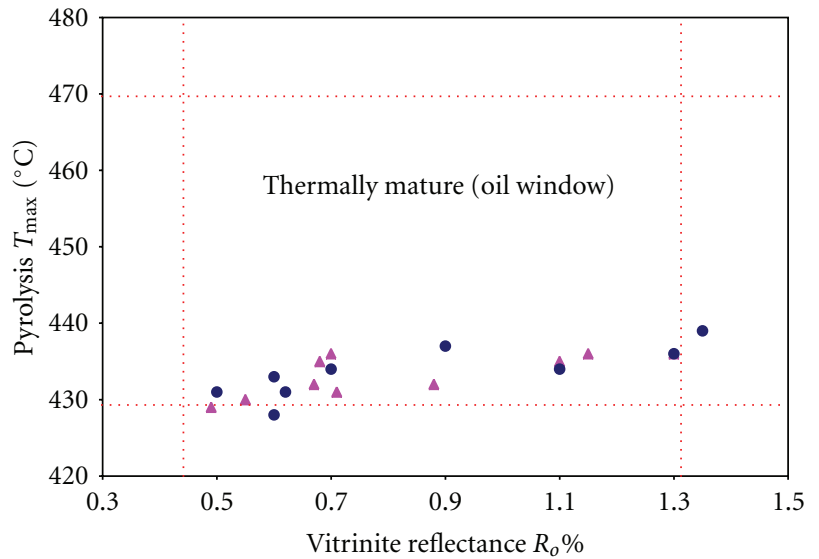

4 Abu Madi-11 well

- Abu Madi-9 well

FIGURE 3: Plot of $T_{\max }$ versus Vitrinite reflectance values $\left(R_{o}\right)$, showing good agreement between $T_{\max }$ and Vitrinite reflectance data.

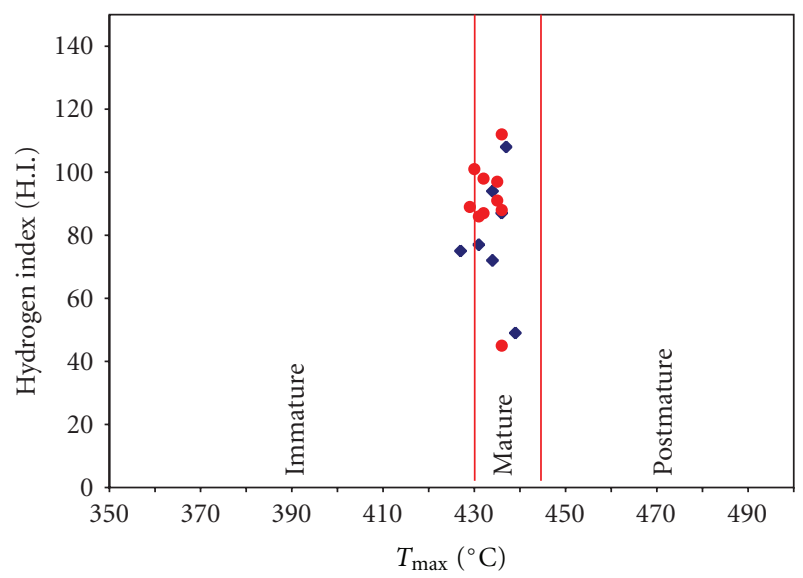

- Abu Madi-9 well data

- Abu Madi-11 well data

Figure 4: Plot of $T_{\max }$ versus H.I. for the analyzed samples from Abu Madi-9 and Abu Madi-11 wells well.

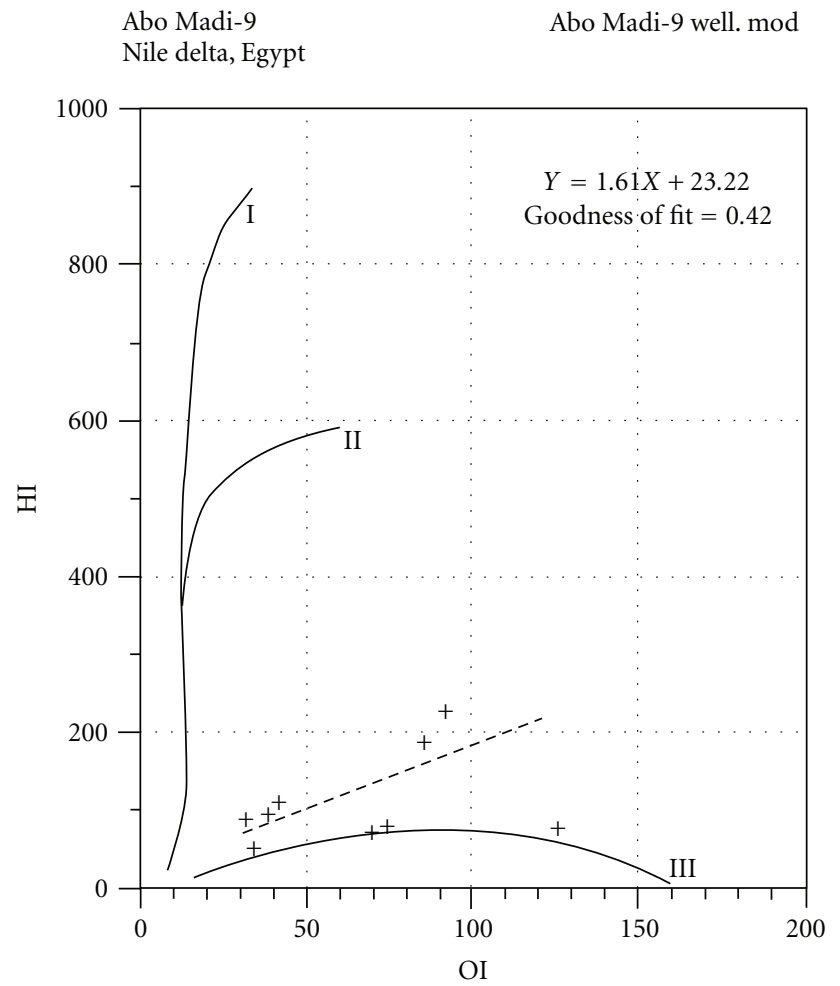

Figure 5: Plot of Oxygen index versus hydrogen index for the analyzed samples from Abu Madi-9 well.

River (2003) software in addition to kerogen data measured by Khaled et al. [7], these samples were taken from Abu Madi formation and they represent a depth interval from $3067 \mathrm{~m}$ to $3390 \mathrm{~m}$ in well Abu Madi-9 and, $3108 \mathrm{~m}$ to $3460 \mathrm{~m}$ in Abu Madi-11 well (Tables 1 and 2).Parameters measured include TOC, S1, S2, S3 and temperature of maximum pyrolysis yield $\left(T_{\max }\right)$. Hydrogen index and oxygen index were calculated as described by Espitalie et al. [8] and peters and Cassa [9].

\section{Modeling Procedures}

To Construct the burial history, the essential input data included formation tops from ground level, absolute time 


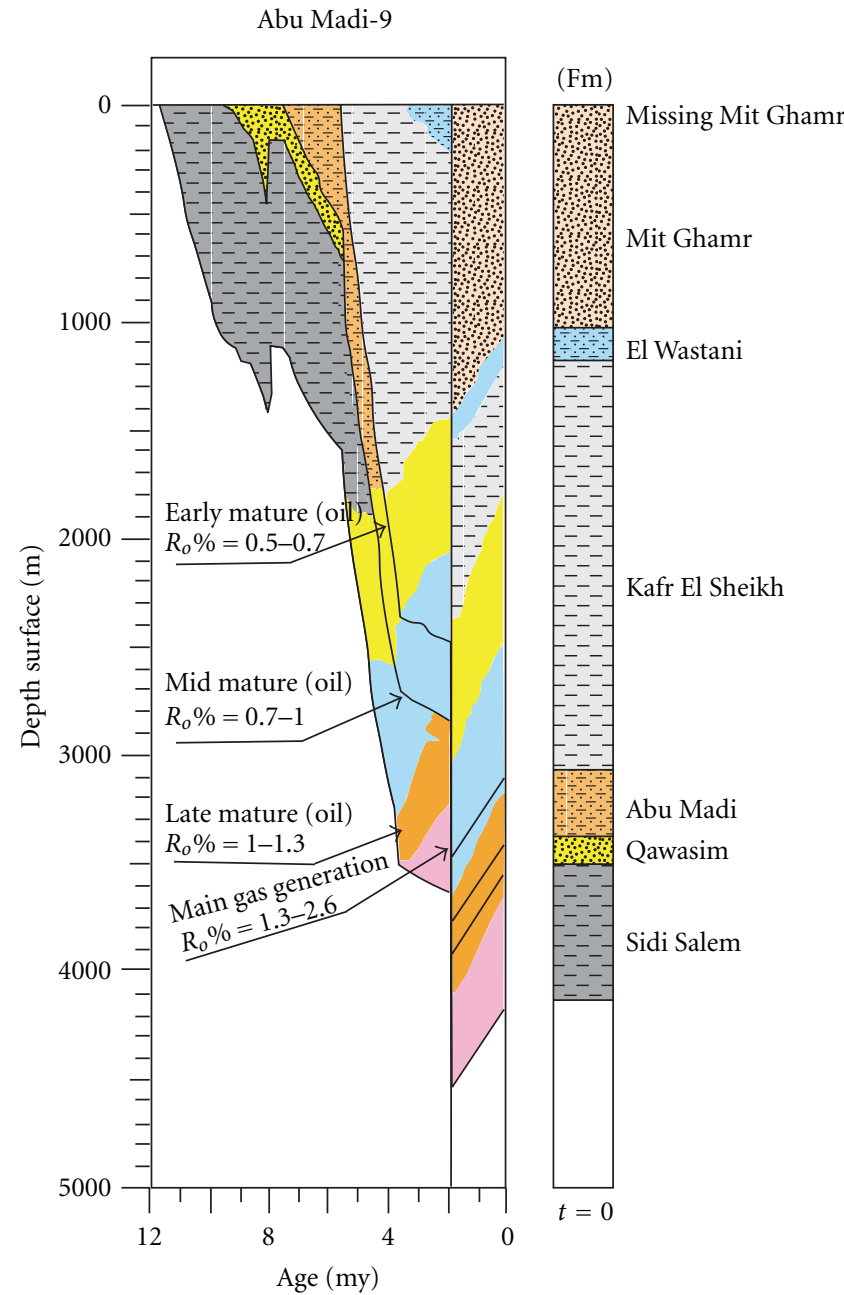

(a)

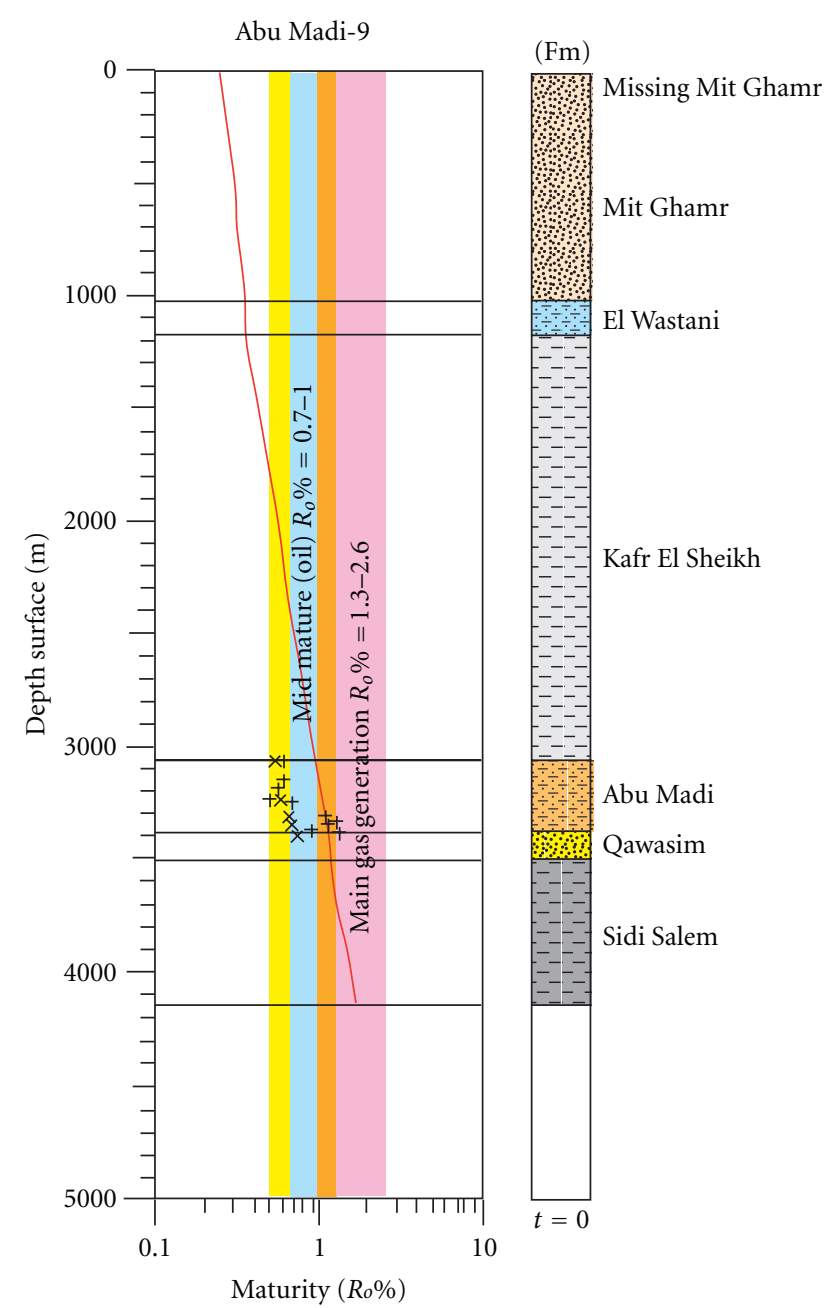

(b)

FIGURE 6: (a) Burial history curve for Abu Madi-9 well showing the calculated maturity (b) the measured maturity for samples taken from Abu Madi formation. Both figures agree the level of maturity for Abu Madi formation (early to mid mature).

of deposition in Ma (millions of years), lithological composition, hiatus age, thickness and age of eroded intervals, and the heat flow data calculated from observed geothermal gradients. The study area had sufficient information for modeling. Absolute age in many of the different stratigraphic units was defined using the global stratigraphic chart complied by Cowie and Bassett [10]. The lithological composition of the stratigraphic units was obtained from composite logs, whereas the average porosities and densities of these reservoir units were determined from petrophysical analysis.

In the basin modeling, the sedimentary sequence at the wells is subdivided into layers from the Tortonian (12 Ma) to the present and have vertical continuity in lithology and lateral continuity in time. The vertical continuity is essential to correctly compute pressure and temperature histories. The lateral continuity in time is needed to accurately define chronostratigraphy and to plot the result at any time during the geologic history [11].

\section{Source Rock Evaluation}

6.1. TOC and Pyrolysis Data. Total organic carbon (TOC) of samples from Abu Madi formation (Tables 1 and 2) ranges from 0.51 to $2.03 \mathrm{Wt} \%$ which is considered good potential source rock. The migration index (S1/TOC) ranges from 0.03 to $0.49 \mathrm{mg} \mathrm{HC/g}$ TOC with an average value of $0.11 \mathrm{mg} \mathrm{HC} / \mathrm{g}$ TOC. This value lies in the range of 01$0.2 \mathrm{mg} \mathrm{HC} / \mathrm{g}$ TOC suggested by Hunt [13] to characterize the oil expulsion zone. In the Rock-Eval pyrolysis analysis, free hydrocarbons (S1) in the rock and the amount of hydrocarbons (S2) and CO2 (S3) expelled from pyrolysis of kerogen are measured (Tables 1 and 2). In addition, the $T_{\max }$ value, which represents the temperature at the point where the S2 peak is maximum, is also determined [14]. Pyrolysis data from 19 samples from Abu Madi Formation presents low values of S1 (average $0.12 \mathrm{mg} \mathrm{HC} / \mathrm{g}$ rock), S2 value ranges from 0.25 to $2.74 \mathrm{mg} \mathrm{HC} / \mathrm{g}$ rock (average is $1.27 \mathrm{mg} \mathrm{HC} / \mathrm{g}$ rock), the $(\mathrm{S} 1+\mathrm{S} 2)$ range from 0.50 to $2.91 \mathrm{mg} \mathrm{HC} / \mathrm{g}$ rock 


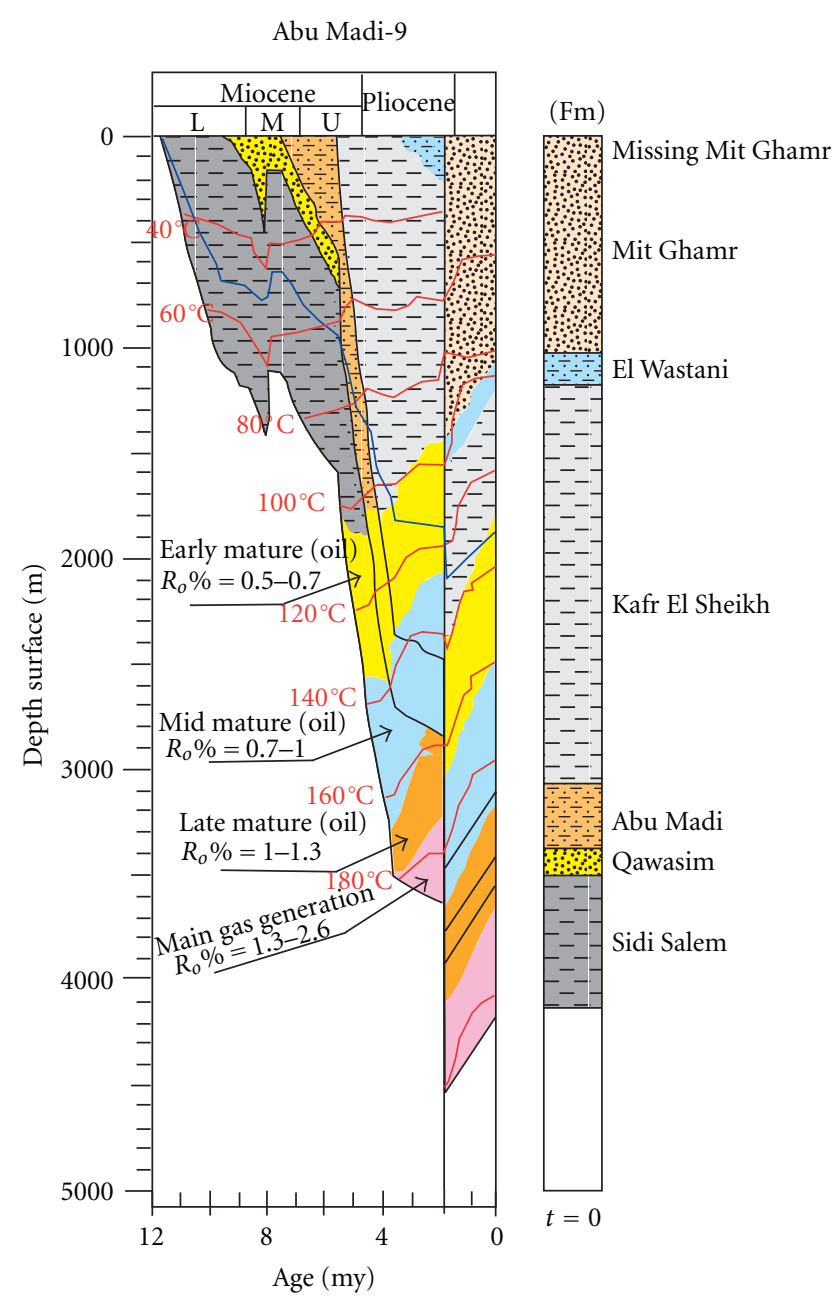

FIGURE 7: Burial history curve for Abu Madi-9 well showing kinetic window of stratigraphic units.

(average $1.38 \mathrm{mg} \mathrm{HC} / \mathrm{g}$ rock). The calculated S2/S3 equals 1.3 (less than 2).These values indicate gas-prone organic matter and poor to fair hydrocarbon generation potential. The values of Production Index (PI) expressed by $\{S 1 /(S 1+S 2)\}$ range from 0.04 to 0.5 (average 0.11 ) lie in the range of oil window [13]. Accordingly, organic matter in mudstone bed within Abu Madi formation is suggested to be fairly mature and gas prone; they have reached the early oil generation zone very close to the roof of the oil window.

6.2. Vitrinite Reflectance. The vitrinite reflectance $R_{o}$ values range from 0.5 to $1 \%$ indicating that the samples are thermally mature and have entered the mature to late mature stage of hydrocarbon generation. This is supported by pyrolysis $T_{\max }$ values as shown in Figure 3 .

6.3. Type of Organic Matter. The stage of maturity can be estimated using the temperature of maximum pyrolysis yield $\left(T_{\max }\right)$, although this is partly dependent on other factors such as the type of organic matter or mineral matrix effects [9]. In general, $T_{\max }$ values less than $435^{\circ} \mathrm{C}$ indicate

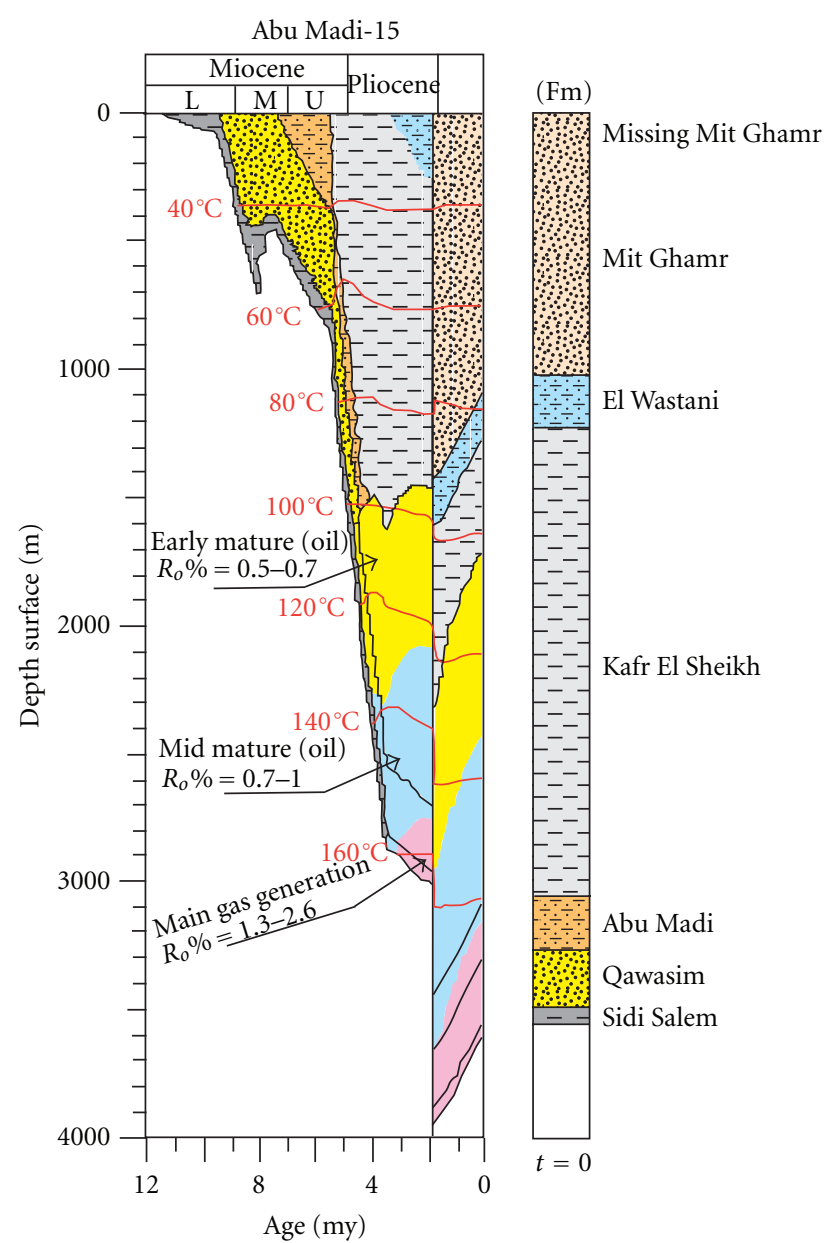

FIgURE 8: Burial history curve for Abu Madi-15 well showing kinetic window of stratigraphic units.

immature organic matter, whereas values of about $445^{\circ} \mathrm{C}$ indicate the end of the oil window and the beginning of the wet gas zone [8]. A plot of $T_{\max }$ versus hydrogen index from Abu Madi-9 and Abu Madi-11 wells is shown in Figure 4. The maturity stages determined from this plot (Figure 4) indicate that the kerogen of mature type agrees with that determined from vitrinite reflectance.

The hydrogen index ( $\mathrm{HI}=\mathrm{S} 2 / \mathrm{TOC})$ versus oxygen index $(\mathrm{OI}=\mathrm{S} 3 / \mathrm{TOC})$ plot on the Van Krevelen diagram $[15,16]$, for the data from Abu Madi-9 well is shown in Figure 5. The plot indicates the predominance of organic matter of type III.

6.4. Thermal Maturity of Organic Matter. The heat flow history of a basin is proposed by establishing an agreement between a calculated (or modeled) maturity parameter and the equivalent observed maturity parameter (such as vitrinite reflectance or Rock-Eval $T_{\max }$ ). The maturity profile (Figure 6) reveals a good match between the measured and calculated vitrinite reflectance values. Windows boundary of oil and gas varies with type of organic matter, ranging from $0.5 \%$ to $1.0 \% R_{o}$ and $1.3-3.5 R_{o}$, respectively $[14,16]$. Generally, vitrinite reflectance values increase with depth due 


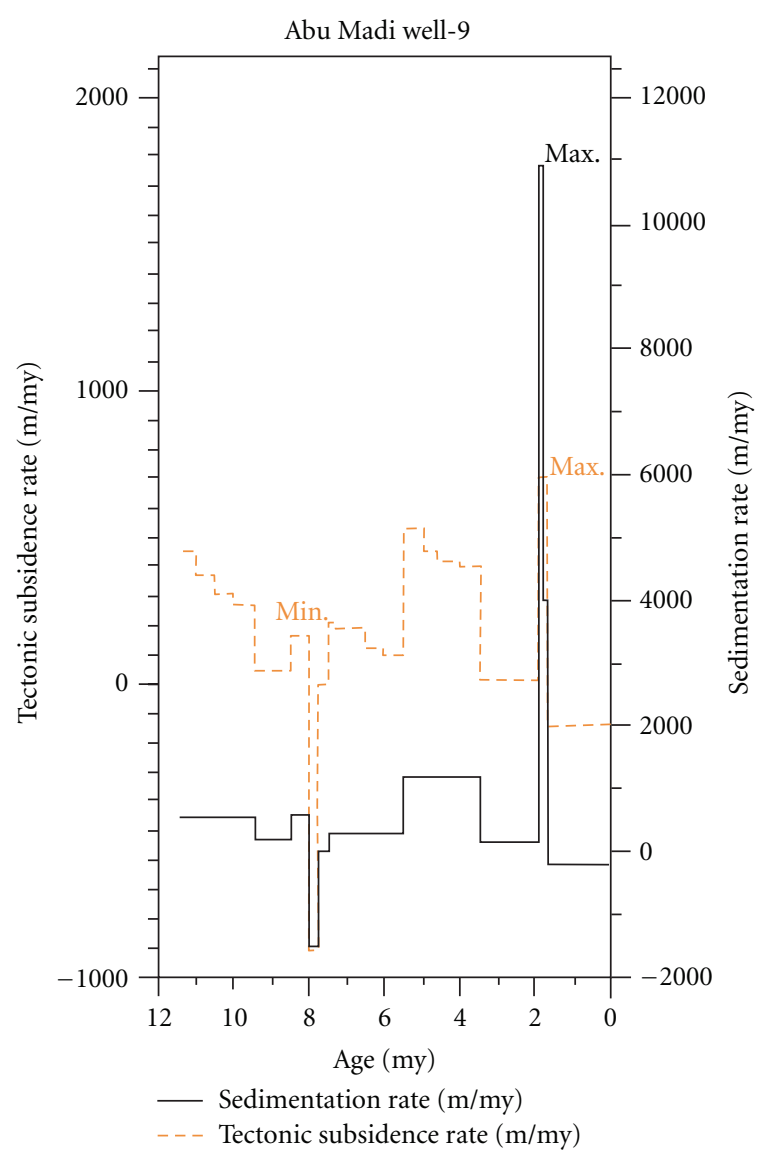

Figure 9: Tectonic subsidence rate for Abu Madi-9 well, showing period of nondeposition and period of increasing rate of subsidence/sedimentation.

to an increase in temperature and age of the rock with depth. The available data generally suggest that the majority of the kerogen of Abu Madi formation belong to mature type III in the principal zone of oil generation (oil window), where $R_{o}$ values range from 0.5 to $1 \%$, with small amounts of kerogen immature type III, where $R_{o}$ is less than $0.5 \%$. Figure 3 shows distribution of vitrinite reflectance data indicating that the samples taken from late Miocene Abu Madi formation are sufficiently thermally mature (oil window) for hydrocarbon generation (Figure 3).

\section{Numerical Modeling}

7.1. Burial History. Supporting evidence for the existence of prolific petroleum systems in the Abu Madi/El Qar'a gas field area comes from basin modeling in the area, which incorporated an analysis of the petroleum system criticals [17]. For effective exploration, a better understanding of the processes that led to the generation, migration, and accumulation of hydrocarbons is necessary. The purpose of the modeling is to evaluate the maturity of the potential source rocks and to estimate their timing of generation and expulsion. The calculated maturities of the potential source rocks were calibrated against the available measured maturity

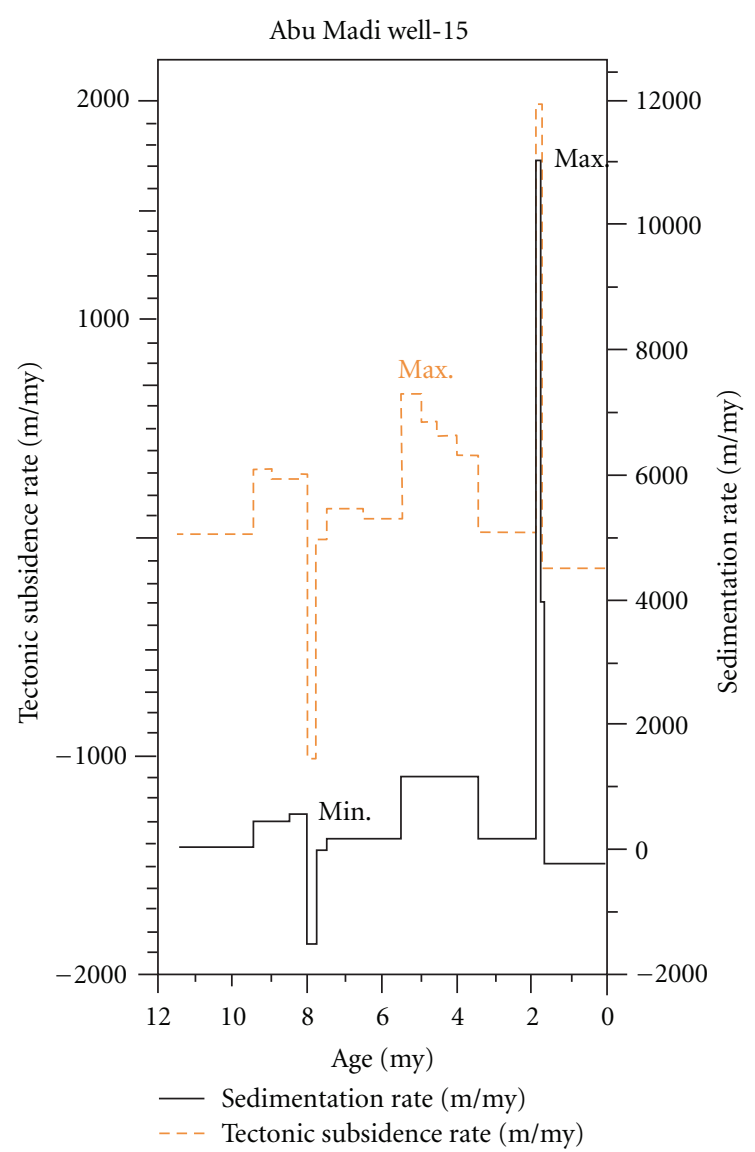

Figure 10: Tectonic subsidence rate for Abu Madi-15 well, showing period of nondeposition and period of increasing rate of subsidence/sedimentation.

parameters, which included mainly vitrinite reflectance data $\left(\% R_{o}\right)$.

The burial history curves of two wells penetrating the study area are shown in Figures 7 and 8. Theses curves show the subsidence history of Abu Madi-09 and Abu Madi15 wells including both steady state and rifting where the Basin mod software uses two basic assumptions for heat flow histories. The steady state uses a constant heat flow over time, whereas the nonsteady state (rifting) uses a variable heat flow over time. These curves (Figures 7 and 8 ) reveal three distinct pluses of subsidence and uplift. These pluses are from 12 to $5.5 \mathrm{Ma}$, from 5.5 to $3.5 \mathrm{Ma}$ and from $3.5 \mathrm{Ma}$ to the present.

The burial history in Abu Madi/El Qar'a field is characterized by a relatively low rate of sediment accumulation from 12 to $5.5 \mathrm{Ma}$ in the middle to upper Miocene (Tortonian-Messinian), during the deposition of Sidi Salem, Qawasim, and Abu Madi formations. A relatively brief period of uplift and erosion occurred between 8.5 and 7.5 Ma and it was ended with deposition of Abu Madi formation.

The rate of deposition increased substantially between 5.5 and $3.5 \mathrm{Ma}$ in the lower Pliocene during deposition of Kafr El Sheikh formation, when most of the sediments (between $1810 \mathrm{ft}$ to $2003 \mathrm{ft}$ ) were deposited. A slowing rate of sedimentation in the upper Pliocene occurred during 


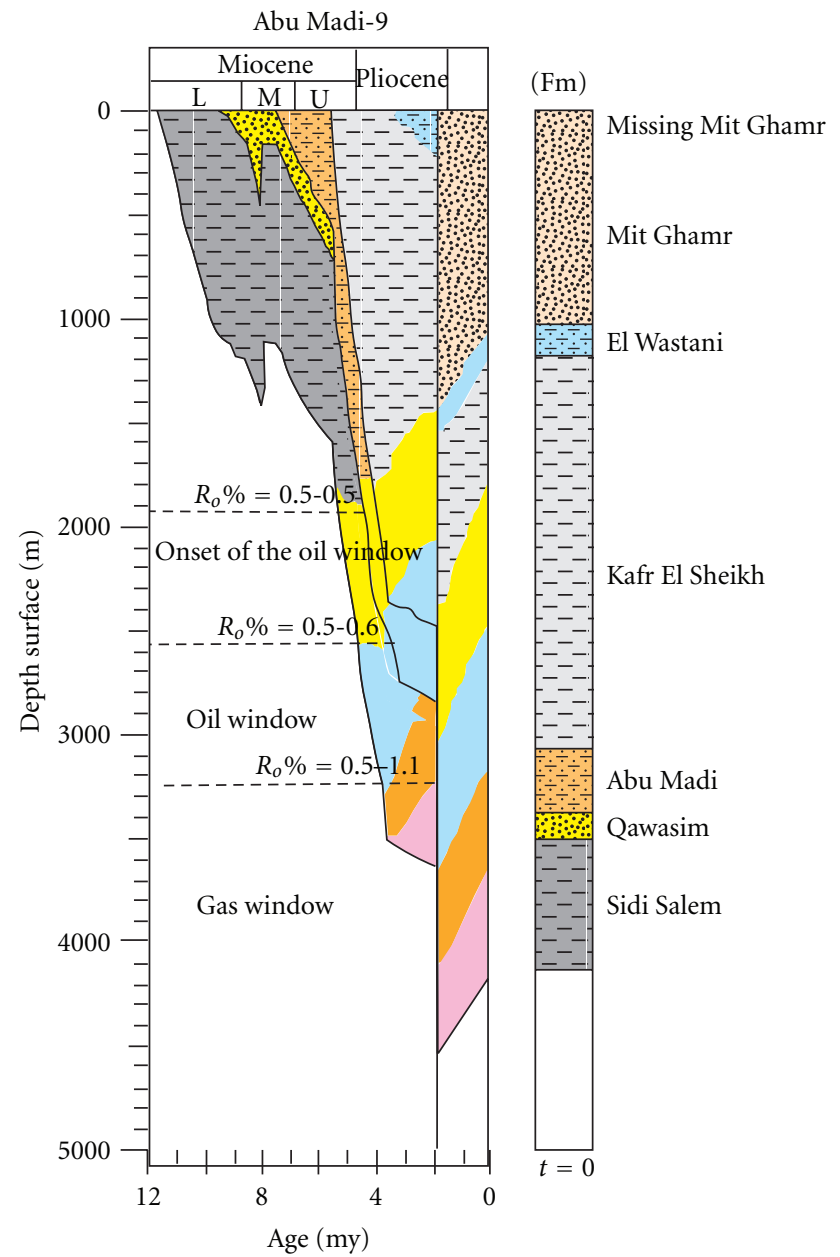

FIGURE 11: Burial history curve with hydrocarbon zones for the Abu Madi and Sidi Salem formations.

deposition of El Wastani formation. This is followed by more rapid, post upper Pliocene, burial from 1.9 Ma to recent during deposition of Mit Ghamer formation.

7.2. Tectonic Subsidence Curves. The tectonic subsidence curves of the two selected wells are shown in Figures 9 and 10. These illustrate the tectonic subsidence and sedimentation rate in the Abu Madi/El Qar'a field area. The curves clearly show the period of non deposition that occurred in the Middle Miocene, prior to deposition of the Abu Madi Formation (from 8.5 to $7.5 \mathrm{Ma}$ ). The curves also reveal the existence of two periods marked by an increase of subsidence/sedimentation rate, during deposition of Kafr El Sheikh and Mit Ghamer Formations.

\subsection{Timing of Hydrocarbon Generation of Miocene Source} Rocks. The timing of hydrocarbon generation from the Miocene Abu Madi and Sidi Salem formations in the studied wells was analyzed and determined based on temperature and maturation history. Petroleum generation stages were calculated assuming mainly type III kerogen and using a

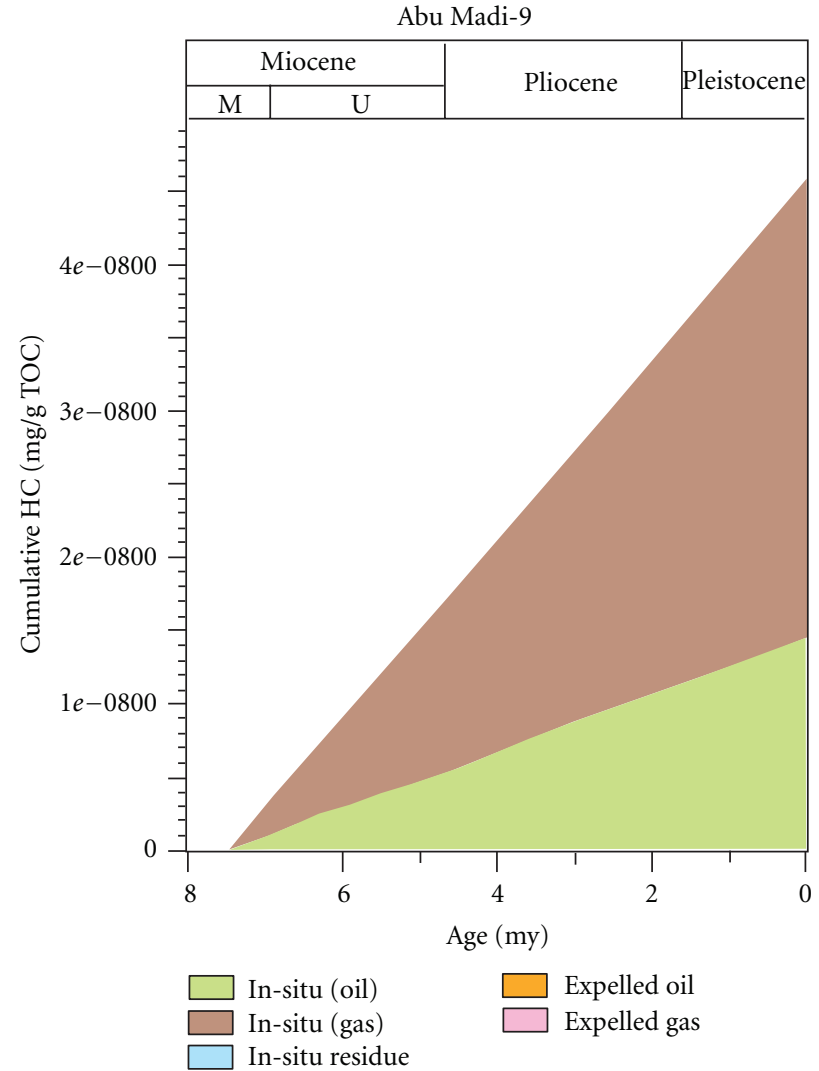

FIGURE 12: Calculated (cumulative model) of hydrocarbon generation from organic matter in the Abu Madi formation from Abu Madi-9 well, Abu Madi/El Qar'a Gas field.

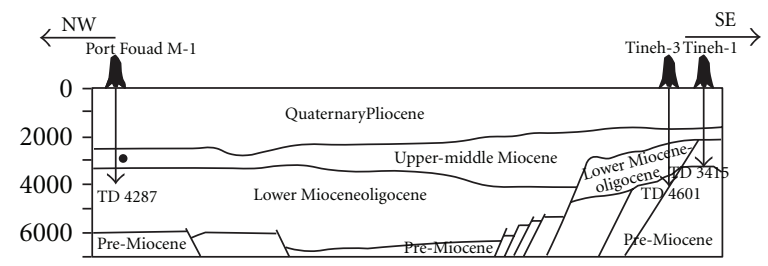

(a)

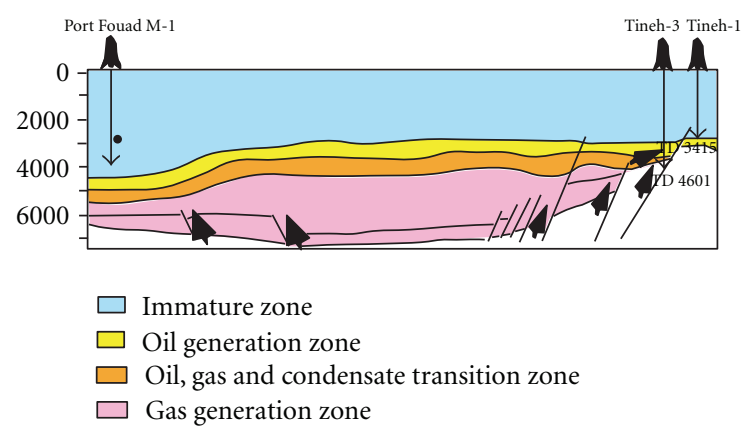

(b)

FIGURE 13: NW-SE cross sections showing the migration paths through the Nile Delta (modified after [12]). 


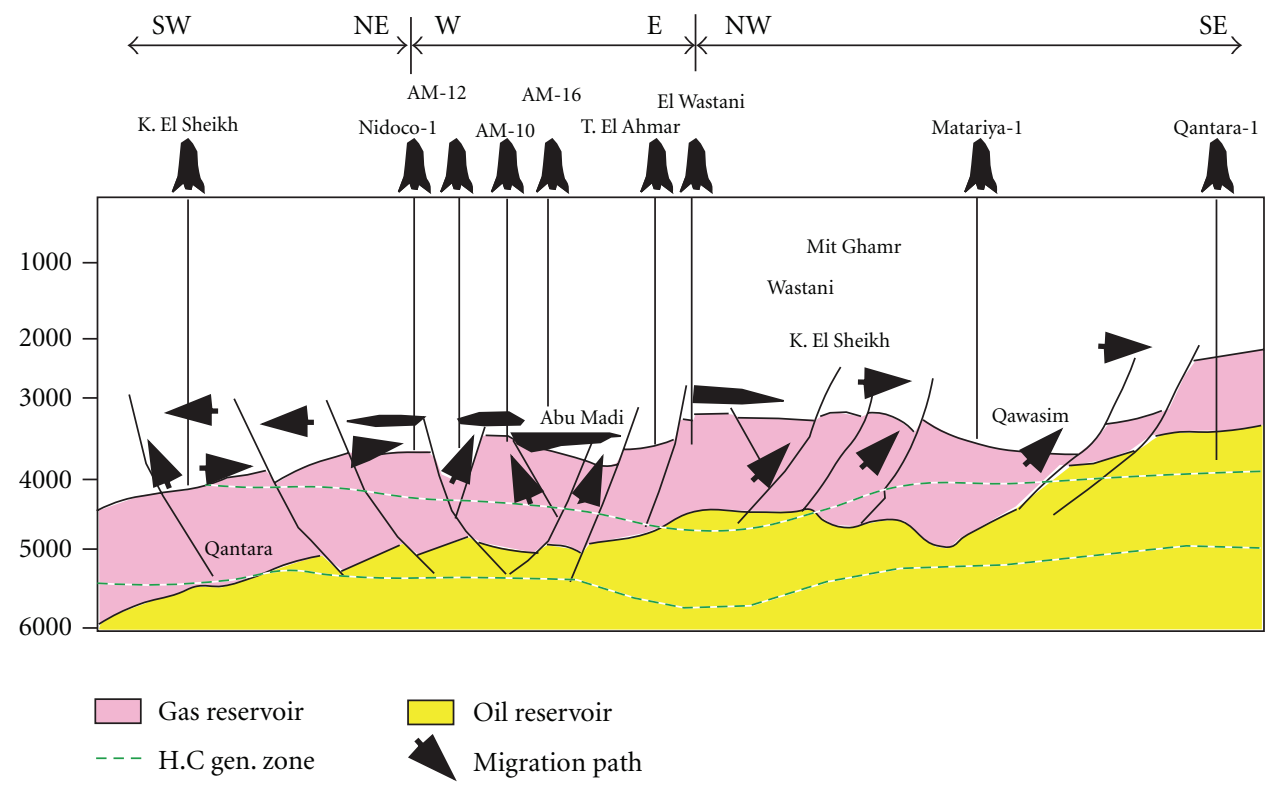

FIGURE 14: Hydrocarbon reservoirs and migration paths through the Nile Delta (modified after [12]).

reaction kinetic data set based on Burnham [18]. The modeled hydrocarbon generation from Abu Madi-9 well is shown in Figure 11. This model shows that the corresponding to onset of the oil window $\left(0.5-0.6 R_{o}\right)$ of the Miocene source rocks was during early Miocene at depths greater than $2000 \mathrm{~m}$ (Figure 11). The Miocene source rocks reached late mature stage at middle to upper Miocene age and the gas window in upper Miocene to lower Pliocene. Accordingly the hydrocarbon generation (oil and gas) started in middle to upper Miocene and peak hydrocarbon generation occurred during lower Pliocene (Figures 11 and 12).

In the area of study geochemical analysis from two wells (Abu Madi-9 and Abu Madi-11) and burial history curves were taken to identify and characterize rich source intervals that probably the source of hydrocarbons, where organic matter $(\mathrm{OM})$ in mudstone beds within Abu Madi Formation and shale beds of Sidi Salem formation is considered as effective hydrocarbon source rocks in study area.

\section{Migration and Entrapment}

Understanding the process of hydrocarbon generation and migration coupled with good geological data will assist to predict the ultimate hydrocarbon accumulations. The generation and migration of the hydrocarbons are thought to have reached their peak at the end of Miocene. This occurred after the main structural features had been imposed on the area and the main reservoirs had been deposited [12].

Migration along faults is responsible for vertical migration pathways from mature source rocks to shallower reservoirs (Figures 13 and 14). The presence of deep-cut channels, old valleys during Messinian, and the unconformities allows a good path for lateral updip migration and further entrapment in the shallow closures [12].
In the study area, where the shallow Pliocene growth faults are not well developed, only the normal fault pattern plays the main role in the vertical migration for the generated hydrocarbons and its ultimate entrapment and accumulation in the Miocene and older reservoirs. The possibilities of finding out commercial Pliocene gas accumulation are relatively low and depending on the presence of syndepositional growth faults in the Pliocene.

\section{Conclusions}

Majority of Abu Madi kerogen belongs to mature type III in the principal zone of oil generation (oil window), $R_{o}$ values range from 0.5 to $1 \%$. With small amounts of kerogen immature type III, where $R_{o}$ is less than $0.5 \%$. Plot of hydrogen index versus oxygen index also indicates the predominance of organic matter of type III.

Subsidence history of Nile Delta basin classified into two phases, the first phase from early Cretaceous to middle Miocene is a mechanical (faulted-controlled) subsidence phase prevailed which continued from subsidence initiation $(9 \mathrm{Ma})$ to $(3 \mathrm{Ma})$. The second phase is a nonmechanical (thermal-controlled) subsidence from $(3 \mathrm{Ma})$ and continued through Tertiary.

Numerical modeling of various wells indicates that onset of the oil window (0.5-0.6 $R_{o}$ ) of the Miocene source rocks was during early Miocene at depths greater than $2000 \mathrm{~m}$. The Miocene source rocks reached late mature stage at middle to upper Miocene age and the gas window in upper Miocene to lower Pliocene. Accordingly the hydrocarbon generation (oil and gas) started in middle to upper Miocene and peak hydrocarbon generation occurred during lower Pliocene.

The maturation modeling of the study area revealed that the hydrocarbon compositions (gas and condensate) of Abu 
Madi formation are sourced from both mudstone beds in Abu Madi Formation and shale beds of Sidi Salem formation, where vitrinite reflectance estimated from models Maturity degree of Abu Madi Formation is early mature according to Vitrinite Reflectance determined from models $\left(R_{o}\right.$ range from 0.5 to 0.76 ) and Sidi Salem formation to main gas generation zone ( $R_{o}$ range from 1.3 to 2.6 ).

\section{References}

[1] Z. M. Zaghloul, A. A. Taha, and A. Gheith, Microfacies studies and paleo-environmental trends on the subsurface sediments of Kafr el sheikh well no. 1, vol. 5 of Nile Delta Area, Bulletin, Faculty of Science, Mansoura University, 1977.

[2] L. M. Sharaf, "Source rock evaluation and geochemistry of condensates and natural gases, offshore Nile Delta, Egypt," Journal of Petroleum Geology, vol. 26, no. 2, pp. 189-209, 2003.

[3] I. El-Heiny and N. Enani, "Regional stratigraphic interpretation pattern of Neogene's sediments, Northern Nile Delta, Egypt," in Proceedings of the 13th EGPC, Exploration and Production Conference, Cairo, Egypt, 1996.

[4] EGPC (Egyptian General Petroleum Cooperation), Nile Delta and North Sinai: A Field, Discoveries and Hydrocarbon Potentials (A Comprehensive Overview), Egyptian General Petroleum, Cairo, Egypt, 1994.

[5] M. Alfy, F. Polo, and M. Shash, "The geology of Abu Madi Gas Field," in Proceedings of the 11th Petroleum Exploration and Production Conference, EPGC, Cairo, vol. 2, pp. 485-513, 1992.

[6] M. Sarhan and K. Hemdan, "North Nile Delta structural setting and trapping mechanism, Egypt," in Proceedings of the 12th Petroleum Conference of EGPC, vol. 12, no. 1, pp. 1-17, Cairo, Egypt, 1994.

[7] K. A. Khaled et al., "Maturation and source-rock evaluation of mudstone beds in Abu Madi and Kafr el Sheikh Formations," in Proceedings of the Abu Madi Gas Field, Nile Delta, Egypt, Annals of the Egyptian Geological Survey, vol. 26, pp. 449-474, 2004.

[8] J. Espitalie, M. Madec, B. Tissot, J. J. Mennig, and P. Leplat, "Source rock characterization, methods of petroleum exploration," in Proceedings of the Offshore Technology Conference, vol. 3, no. 9, pp. 439-444, May 1977.

[9] K. E. Peters and M. R. Cassa, "Applied source rock geochemistry," in The Petroleum System, from Source to Trap. AAPG Mem, B. Magoon Leslie and W. G. Dow, Eds., pp. 93-120, 1994.

[10] J. W. Cowie and M. G. Basset, "Global stratigraphic chart with geochronometric and magneto-stratigraphic calibration," in International Union of Geological Sciences, vol. 12, no. 2, 1989.

[11] M. A. Yukler and Welte, "A three-dimensional deterministic dynamic model to determined geologic history and hydrocarbon generationmigration and accumulation in a sedimentary basin: Fossil Fuels," 1980.

[12] H. Kamel, T. Eita, and M. Sarhan, "Nile Delta hydrocarbon potentiality," in Proceeding of the 14th Petroleum Conference, vol. 12, pp. 485-503, EGPC, Cairo, Egypt, October 1998.

[13] J. M. Hunt, Petroleum Geochemistry and Geology, W. H. Freeman, New York, NY, USA, 2nd edition, 1996.

[14] J. Espitalie, "Use of Tmax as a maturation index for different types of organic matter-comparison with vitrinite reflectance," in Thermal modeling in Sedimentary Basins, J. Burrus, Ed., pp. 475-496, Editions Technip, Paris, France, 1985.
[15] D. W. Van Krevelen, "Organic geochemistry-old and new," Organic Geochemistry, vol. 6, pp. 1-10, 1984.

[16] B. P. Tissot and D. H. Welte, Petroleum Formation and Occurrence, Springer, 2nd edition, 1984.

[17] F. I. Metwalli and J. D. Pigott, "Analysis of petroleum system criticals of the Matruh-Shushan Basin, Western Desert, Egypt," Petroleum Geoscience, vol. 11, no. 2, pp. 157-178, 2005.

[18] A. K. Burnham, A simple kinetic model of petroleum formation and cracking Lawrence Livermore National Laboratory Report UCID-21665, 1989. 

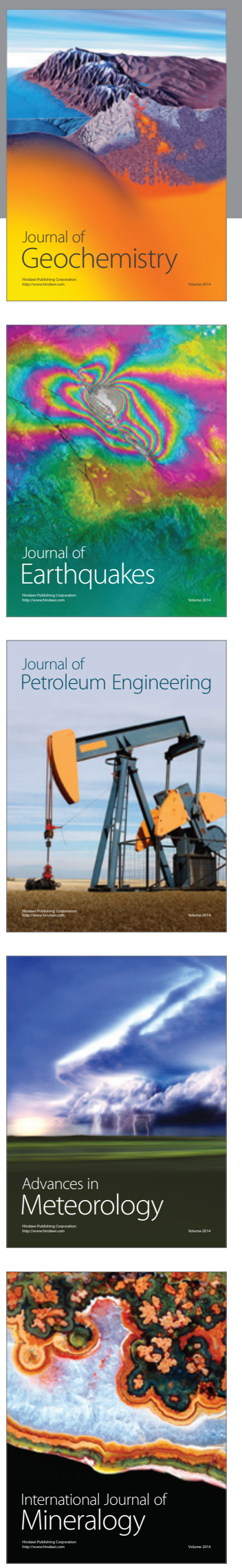
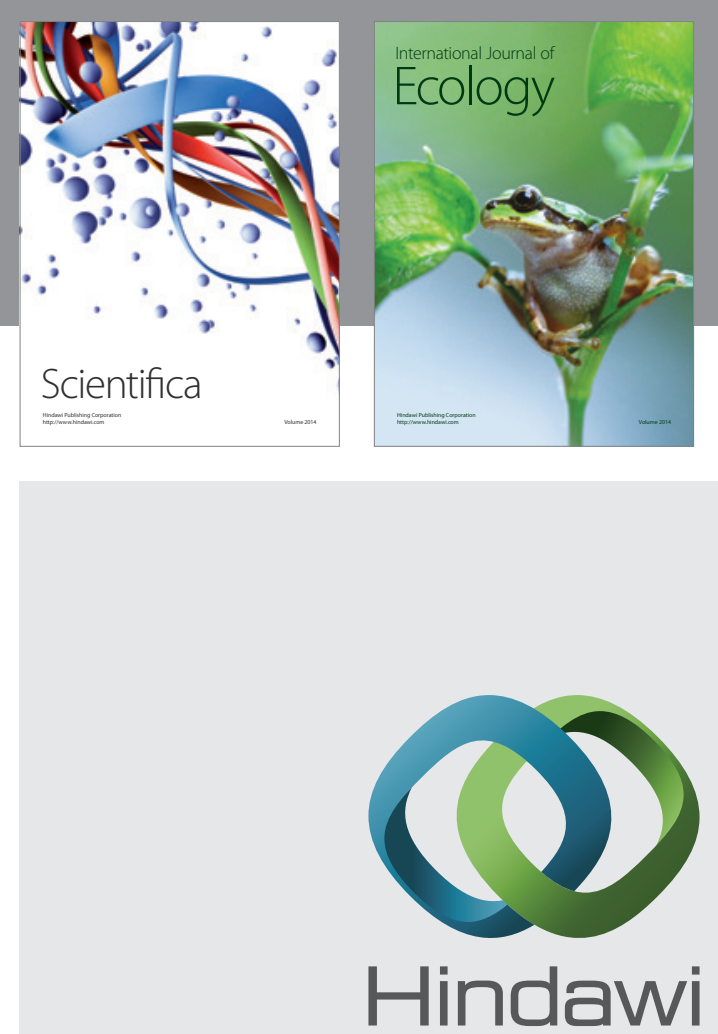

Submit your manuscripts at http://www.hindawi.com
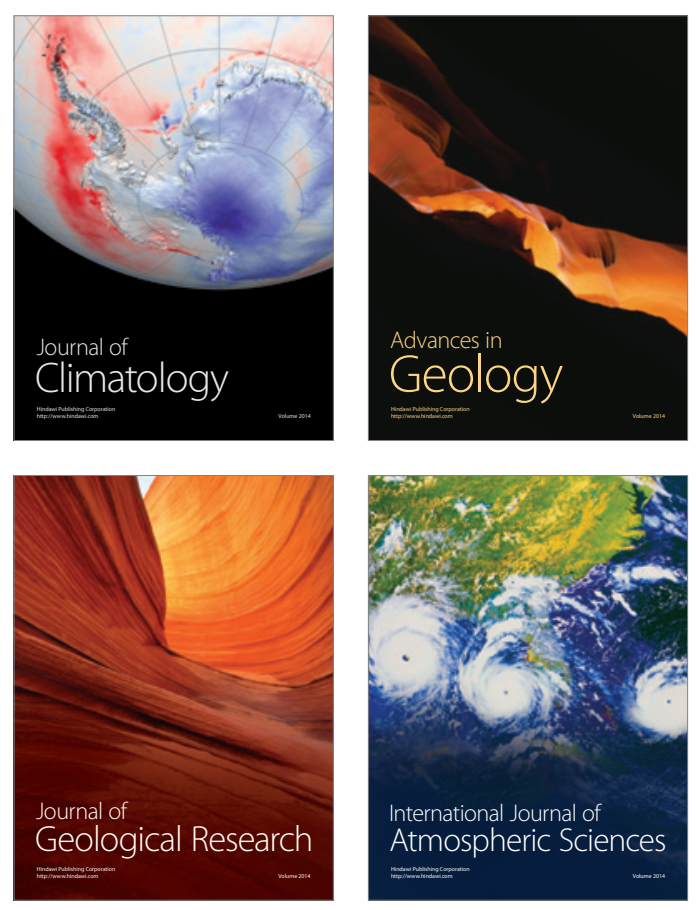
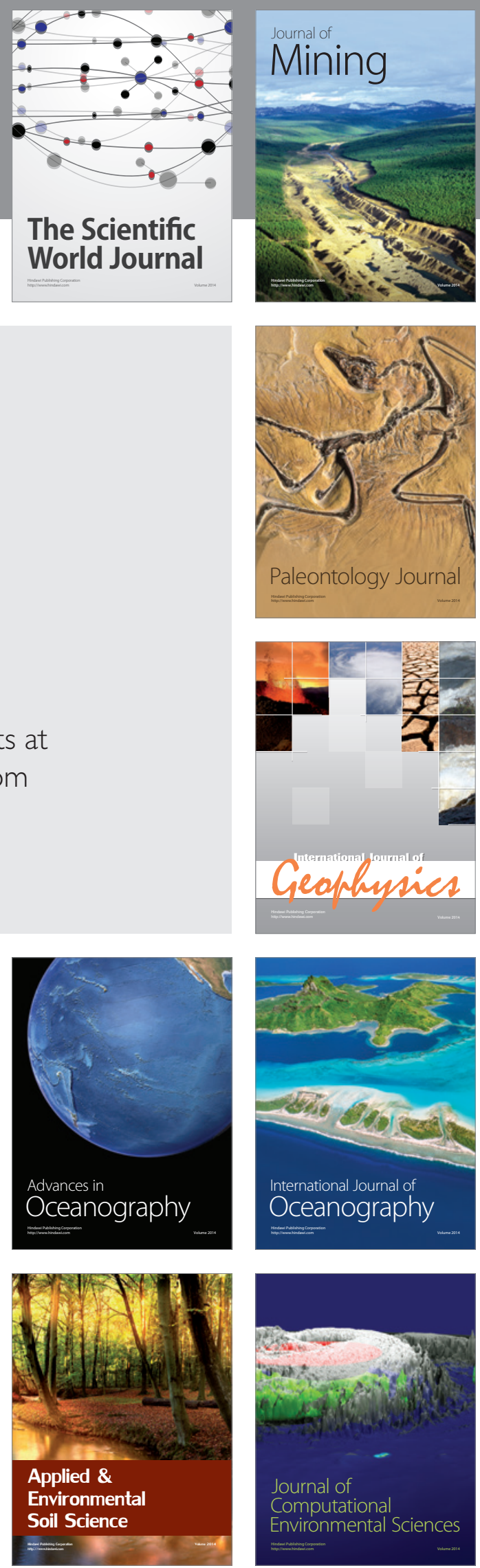